\title{
Brasil y la imaginación novomundana. Acerca de la imagen de América latina y su literatura
}

\author{
LEONEL CHERRI Universidad de Buenos Aires - CONICET, Argentina / clcherri@hotmail.com
}

\section{Resumen}

Este trabajo tiene por objeto retornar, anacrónica (Didi-Huberman) y rapsódicamente (Antelo 2013), a una serie de experiencias brasileñas en las que podemos leer distintas imágenes de la literatura y de las artes latinoamericanas cuya singularidad y potencia conviene interrogar. Este mandato a la vez crítico y ético se desprende del recorrido que Brasil ha ocupado en la construcción del campo de la literatura latinoamericana y en la imagen misma de América Latina.

Por lo tanto, nos proponemos detenernos en unas figuras que desde 1492 al presente aparecen con insistencia en la literatura y las otras artes latinoamericanas agitando sus potencias imaginarias. Me refiero a las sirenas, a los caníbales, a lo primitivo, a lo térreo, a lo orgánico y a lo mágico. Se tratan de figuras y/o elementos paradigmáticos que ponen de relieve a Brasil en relación con la imagen de América Latina.

Palabras clave: América Latina / Brasil / imagen / imaginación

\section{Brazil and the New Welt imagination. About the image of Latin America}

Abstract

This work aims to return, anachronistic (Didi-Huberman) and rhapsodically (Antelo 2013), to a set of Brazilian experiences in which we can read different images of literature and Latin American arts whose singularity and potency should be interrogated. This mandate at the same time critical and ethical, follow de routes that Brazil has occupied in the construction of the field of Latin American literature and in the image of Latin America.

Therefore, we propose focalize in figures that since 1492 at present appear insistently in literature and in the other Latin American arts, stirring their imaginary powers. I refer to sirens, cannibals, the primitive, the crazy, the organic and the magical. This figures and paradigmatic elements highlight the relationship between Brazil and the image of Latin America.

Key words: Latin America / Brazil / image / imagination

Recibido: 23/7/2018. Aceptado: 31/8/2018

Para citar este artículo: Cherri, Leonel (2018). Brasil y la imaginación novomundana. Acerca de la imagen de América latina y su literatura. El taco en la brea, 8 (junio-noviembre), 76-100. Santa Fe, Argentina: UNL. DOI: $10.14409 /$ tb.v1i8.7758 
Porque a mesma terra he tal

E tam favorável aos que vam buscar

Que a todos agasalha e convida

Oswald de Andrade. «Hospedagem». História do Brasil.

Entre aquellos que hacen libros con pretensiones literarias, incluso entre los locos, muy pocos pueden llamarse escritores

Gilles Deleuze. Literatura y vida.

\section{De Américas, modernidades y experiencias secuestradas}

Este trabajo tiene por objeto retornar, anacrónica (Didi-Huberman) y rapsódicamente (Antelo 2013), a una serie de experiencias brasileñas en las que podemos leer distintas imágenes de la literatura y de las artes latinoamericanas cuya singularidad y potencia conviene interrogar.

Este mandato a la vez crítico y ético se desprende del recorrido que Brasil ha ocupado en la construcción del campo de la literatura latinoamericana y en la imagen misma de América Latina. Relato crítico e histórico que más allá de las discusiones que pueda motivar es, hoy en día, ya un estado de la cuestión de los estudios latinoamericanos. No obstante, me gustaría revisitarlo sucintamente.

Está bastante establecido en la crítica que la expresión «América Latina» guarda una relación estrecha con los "peligros imperiales» desde que fue acuñada, a partir de la invasión francesa a México en el 1861 (Fernández Bravo, Scavino, Rojas-Mix, Ardao, Rojas). Para Walter Mignolo, por ejemplo,

resulta claro (...), tal como se sabe históricamente, que las configuraciones geopolíticas del imaginario del subcontinente y el nombre no fueron invenciones de intelectuales latinoamericanos ilustrados en busca de su identidad. Fueron, en cambio, el producto de una nueva configuración en un campo imperial de fuerzas: España y Portugal en decadencia; Francia e Inglaterra en un estadio imperial hegemónico; Estados Unidos con una clara perspectiva acerca de su «destino manifiesto» y un proyecto acerca de su futuro poder imperial. (2003a:204)

Sin embargo, las recientes apreciaciones de Leslie Bethell han demostrado que «En realidad, una serie de escritores e intelectuales hispanoamericanos, muchos de ellos, es cierto, residentes en París, habían usado la expresión "América Latina" varios años antes» (54), básicamente para sostener «la idea (propuesta antes no sólo por Simón Bolívar sino muy notablemente por Andrés Bello) de una conciencia identitaria común, más fuerte que los "nacionalismos" locales y regionales» y que los diferenciaba, a su vez, «de los Estados Unidos, la "otra" América (55). La autora se refiere a María Torres Caicedo, periodista, poeta y crítico colombiano (1830-1889); Francisco Bilbao, intelectual socialista chileno (1823-1865) y Justo Arosemena, jurista, político, sociólogo y diplomático panameño-colombiano (1817-1896). Es decir, fueron americanos que residían en París y no, simplemente, parisinos o europeos los que acuñaron el término «América Latina».

Más allá de este nuevo debate que se abre, el uso estandarizado del término "América Latina» se propuso designar un subcontinente distinto de la América Anglo-Sajona y tuvo un origen, ahora lo sabemos, americano y no europeo o, si se quiere, americano-europeo. Sin embargo, con el término se identificó inicialmente a la América de habla española. Recién a mediados del siglo XX, su área referencial comienza a ensancharse y empieza a incluir otras regiones como la del Caribe 
francés, la provincia de Québec en Canadá y, fundamentalmente, al Brasil (Coutinho:256, AA. VV.). Esa exclusión —inclusión retardada — de Brasil dentro de esta denominación modeló la forma de pensar, es decir, de imaginar América Latina. Problemática que, como veremos más adelante, llega hasta el presente. Pero detengámonos antes en ese roteiro o derrotero de Brasil en la idea de América Latina o, mejor, Hispánica.

Luego de las independencias del siglo XIX, el modernismo literario de entre siglos desarmó la dialéctica amo-esclavo colonial por la vía de un trilema. Especialmente Rubén Dario en el «El triunfo de Calibán», al afirmar que «la España que yo defiendo se llama Hidalguía, Ideal, Nobleza; se llama Cervantes, Quevedo, Góngora, Gracián, Velázquez; se llama el Cid, Loyola, Isabel; se llama la Hija de Roma, la Hermana de Francia, la Madre de América» (1898:455). Allí, Estados Unidos se presenta como una monstruosidad tecno-capitalista (del norte parten «tentáculos de ferrocarriles» $\mathrm{y}$ «bocas absorbentes») que intenta captar el resto de América: «Venezuela se deja fascinar por la doctrina Monroe», en Perú «hay manifestaciones simpáticas por el triunfo de Estados Unidos; y el Brasil, penoso es observarlo, ha demostrado más que visible interés en juegos de daca y toma con el Uncle Sam» (455).'

Dada esa situación geopolítica en la que «está a la vista la gula del norte, no queda sino preparar la defensa»: es decir, construir un orden imaginario donde Europa, y no ya meramente España —recordemos que «mi esposa es de mi tierra, mi querida, de París» (Dario 1986:I, 180) — sea el índice de «aquella antigua semilla» que se fecunda «desde Méjico hasta la Tierra del Fuego» y prepara «la futura grandeza de nuestra raza» (454). Es decir: «el norte es Calibán, Europa es Ariel, y América es, además de la tensión entre los otros dos, también la casa del piel roja, la semilla antigua y la selva propia, es decir: lo no categorizado de la autoctonía y el espacio liso» (Link, 2015:143). Por eso mismo, el pensamiento de José Enrique Rodó — dialéctico y dilemático— no puede sino presentarse como una simplificación del planteo dariano. Recordemos que para Rodó, Ariel (1900) se identificará con el idealismo y la espiritualidad que, a su vez, supone un mandato (el de Próspero, ese sabio maestro, es decir Europa) que debe asumir la «juventud hispanoamericana» a la que se dirige, mientras que el «horrible» Calibán representa el materialismo tecno-capitalista que se identifica con la «nordomanía».

Sin embargo, más allá de que la "selva propia» tenga una heterogeneidad constitutiva en la reivindicación del mestizaje que va de Bello a Martí pasando por Bolívar, el modernismo no podrá, sin embargo, resolver la tensión interna entre hispanofonía y lusofonía — propia del suelo americano- más que excluyendo al Otro de «nuestra expresión». Y, por consiguiente, la crítica literaria de las décadas siguientes atravesada por la imaginación hispánica acabará por «desmontar» la selva propia. El «desmonte» es una metáfora empleada por Henríquez Ureña y «representa en 1928 una tarea de limpieza y exploración, casi un trabajo de campo en un territorio salvaje que es preciso ordenar» (Fernández Bravo). Lo que lleva al joven Ureña a distinguir una «América buena» (hispanoparlante) y otra «América mala» (lusoparlante). En ese sentido, dice Ureña:

No hemos renunciado a escribir en español, y nuestro problema de la expresión original y propia comienza ahí. Cada idioma es una cristalización de modos de pensar y de sentir, y cuando en él se escribe se baña en el color de su cristal. Nuestra expresión necesitará doble vigor para imponer su tonalidad sobre el rojo y el gualda (9) (...) Durante los veinte años que corren desde 1907 hasta 1927, la literatura se ha transformado en las dos Américas, la inglesa y la hispánica. (71) 
En 1945 con las conferencias en Harvard, compiladas como Literary Currents in Hispanic America, y dos años después con Historia de la cultura en la América Hispana, tal vez producto de su intercambio epistolar con Alfonzo Reyes —embajador de México en Brasil- como de su visita a Río de Janeiro en 1930, la posición de Ureña se modifica sustancialmente: Brasil ingresa al mundo «hispano» pero el término Latinoamérica se resiste a ser nombrado sin explicación alguna (1945:7).

El desplazamiento que se produce entre un momento y otro no es poco. La imaginación geopolítica de ese comparatismo dejó de presuponer que la singularidad de la literatura es un trabajo con la lengua; que el idioma es el mero cristal de un determinado modo de sentir nacionalcontinental y, por consiguiente, que la expresión de un pueblo, una identidad o una comunidad se juega sólo en esos cruces. Ureña arriba, entonces, a una epistemología radicalmente distinta: las diferencias (de clima, de lengua, de las tradiciones) no significan división ni discordia sino la posibilidad de combinarse como matices diversos de la unidad humana. Esa la utopía o «la heterotopía novomundana» que corre a Ureña de cualquier postura autonomizante para llevarlo hacia un vitalismo filológico y político (Link 2016:254). Pero esa «unidad» o posibilidad de juntura es, precisamente, lo que se encuentra en falta.

Para Ureña, al igual que lo fue para Rubén Dario, es claro que América no es el resultado de un dilema sino de una posición trilemática que, como nos ha señalado Sergio Pitol, supuso una dinámica estratégica: «Alguna vez tuvo que oponer las dos Américas, la sajona y la hispánica, al viejo mundo; otras, las repúblicas americanas y España, a la República anglosajona del Norte». Sin embargo, que la incorporación de Brasil a la «América hispana» no modifique cualitativamente la comprensión de su objeto de estudio, como tampoco influya en los juegos de posicionamientos geopolíticos de su comparatismo expone los «límites» o «umbrales» del latinoamericanismo (Fernández Bravo 2009, 2017). Por eso, tal como sostiene Raúl Antelo, Brasil «es, en este conjunto, tan solo un Vacío», y Ureña se convierte no tanto en un «fundador, un padre o un creador» sino, más bien, «un de-creador, un generador de vacío» (2009:27).

Quizás por eso, la perspectiva latinoamericanista de Ángel Rama toma este vacío como argumento de posibilidad en torno al cual constituirá un pensamiento. Así, para Rama, Ureña es el

crítico literario más perspicaz del periodo (...) quien educado en Estados Unidos había tenido trato con la antropología cultural anglosajona y aspiró a integrarla en una pesquisa de la peculiaridad latinoamericana (hispánica, como prefirió decir) todavía al servicio de concepciones nacionales. (1984:22)

Rama es, como muchos pensadores de su generación, uno de los primeros críticos en poner en relación, no ya «dos Américas», sino dos grandes polos lingüísticos: uno mayoritariamente hispanófono y otro mayoritariamente lusófono atravesados, a su vez pero en menor medida, por un conjunto descomunal de otras lenguas. ${ }^{2}$

Por eso, para la perspectiva culturalista de Rama, era preciso iniciar un «proceso autonómico» que vaya de las literaturas nacionales a la literatura latinoamericana (1973). Como sabemos, la cualidad o punto de juntura de esa literatura supra-regional fue su estatuto trans-cultural. ${ }^{3}$ Nacidas de una violenta y drástica imposición colonizadora — dice Rama— «las letras latinoamericanas nunca se resignaron a sus orígenes y nunca se reconciliaron con su pasado ibérico» (1984:15). Ni resignación ni reconciliación, un estatuto ambivalente — ni esto ni lo otro- para las letras latinoamericanas. Pero mucho antes que Rama y al mismo tiempo que Ureña, Lezama Lima había 
recurrido a esta ambivalencia como al fenómeno de la colonización (inglesa, española, portuguesa) para pensar la potencia de absorción creadora, entendida no solamente como un fenómeno transcultural sino, más bien, imaginario:

En los últimos años, de Spengler o Toynbee, el tema de las culturas ha sido en extremo seductor, pero las culturas pueden desaparecer sin destruir las imágenes que ellas evaporaron. Si contemplamos una jarra minoana, con motivos marinos o algunos de sus murales, podemos, por la imagen, sentir su vivencia actual, como si aquella cultura estuviese intacta en la actualidad, sin hacernos sentir los 1500 años a. de C. en que se extinguió. Las culturas van hacia su ruina, pero después de la ruina vuelven a vivir por la imagen. Ésta aviva las pavesas del espíritu de las ruinas. La imagen se entrelaza con el mito que está en el umbral de las culturas, las precede y sigue su cortejo fúnebre. Favorece su iniciación y su resurrección. (AA. VV::462-463)

Como vemos, hubo que esperar hasta 1972 para que Lezama Lima formule de una vez y para siempre su teoría de la imagen. Sin embargo, ya en la década del cincuenta se puede leer en Lezama Lima una epistemología que separa «nuestra expresión» de fenómenos no sólo lingüísticos sino, incluso, culturales —en pleno auge del culturalismo latinoamericano — para ponerla en un horizonte novomundano por la vía regia de la imagen. ${ }^{4}$

Para Lezama, la imagen se asocia con la fiebre («fiebre de la imago») y la distancia que separa cultura e imágenes tiene que ver con la redención (redimere significa originalmente comprar de nuevo). En esa readquisición de lo viviente, la cultura (como dispositivo de clasificación, como máquina dilemática) queda del lado de la muerte, y la imagen (como potencia de desclasificación) del lado de la vida: «Las culturas van hacia su ruina, pero después de la ruina vuelven a vivir por la imagen» (...) En ese sentido (y no casualmente, porque detrás de los dos está Lucrecio), la concepción de «imagen» en Lezama es un eco de la concepción de «figura» propuesta por Auerbach como clave de la «interpretación figural» que establece entre dos acontecimientos o dos caracteres una conexión en la que uno de ellos no se reduce a ser él mismo, sino que además equivale al otro, mientras que el otro incluye al uno y lo consuma. Los dos polos de la figura están temporalmente separados, pero ambos se sitúan en el tiempo, en calidad de acontecimientos o figuras reales; ambos están involucrados, como ya se ha subrayado reiteradamente, en la corriente que es la vida histórica. (Link 2015:136)

Entonces, si de Ureña a Rama la imagen de América Latina se incorpora en una perspectiva histórico-cultural para pensar su literatura; Lezama la desplazaría a una perspectiva imaginaria (e incluso: posfilológica y poshistórica) cuya analítica tendría por objeto las formas de imaginación por medio de las cuales de un momento dado a otro es posible readquirir (redimir) lo viviente (las formas-de-vida). Y en esa perspectiva, «figura» (en tanto imagen plástica, configuración epistemológica o umbral e índice de una transformación) es una unidad analítica clave. ${ }^{5}$

En la perspectiva de Lezama, el barroco constituye no una mera «expresión» artística o americanista sino todo eso y más: una posición geopolítica, un «arte de la contraconquista» (1957:80). Pero, como sabemos, se trata de un camino que ni Rama, ni su amigo Antonio Cándido no estarían dispuestos a transitar, ni a escuchar: pues ignoraron la voz de Lezama y Barroco. Pues, aunque con los dos críticos la literatura brasileña pareció incorporarse a una nueva teoría y crítica cuya imagen 
posnacional constituyó un nuevo perspectivismo latinoamericano, la imagen de la literatura brasileña que puso a funcionar esa actualización del campo de estudio estableció, sin embargo, una línea de modernidad aún excluyente.

El primero en explicar el problema fue, tal vez, Haroldo de Campos:

Se ao «espiríto do Ocidente» coube encarnar-se nas novas terras da então América Portuguesa, incumbe ao crítico-historiador retraçar o itinerário do parousía desde Logos que, como uma árvore, ou, mais modestamente, um arbusto, teve de ser replantado, germinar, florescer, para un dia, quiçá, copar-se como árvore vigorosa e plenamente formada: a literatura nacional. (1989:15)

En síntesis, así como Brasil fue secuestrada de la literatura latinoamericana, el barroco fue secuestrado de la historia de la literatura brasileña de Cándido por una metafísica de la presencia nacionalitaria y, con ese secuestro, América Latina pierde la experiencia barroca: la semilla, ahora mesiánica, crea en donde la selva desmontada un civilizado bosque. Lo que se secuestra con esa experiencia es, además de toda una epistemología radical, el punto de juntura mismo del latinoamericanismo. Pues Haroldo sitúa la cuestión del origen del barroco novohispano en Gregório de Mattos, Sor Juana, Juan del Valle y Caviedes, Hernando Domínguez Camargo pero «ya antes señala que el manierismo de Luís Vaz de Camões es precursor del barroco de Góngora y de Quevedo. Así, al origen hispano del barroco americano le añade el origen lusitano del barroco español» (Mendoza:26).

En otras palabras, liberar al barroco de su secuestro de la historiografía brasileña, es también liberar a Brasil —en la medida que participa de la tradición lusitana — de su secuestro de la historiografía hispanoamericana. $Y$ «si la consigna no siempre pudo ser plenamente escuchada, o si su escucha nunca termina de suceder, es, entre otras razones, porque no sólo hace del Barroco un "origen" de la expresión americana que arruina la relación con España, sino también porque hace de América el auténtico destino del Barroco, incluso del gongorino» (Díaz 2015a:62).

Esta misma idea ha retornado en el presente por medio de un planteo que la profundiza. Recientemente, el gesto crítico de Haroldo fue repetido por Antelo para decir que un secuestro similar practica Rama con la experiencia barroca de Glaubert Rocha en relación con la modernidad hegemónica:

Quisiera demostrar esa hipótesis a partir de una escena emblemática. En 1971, en una de las sesiones de la Quinta Muestra del Cine Latinoamericano de Génova, el crítico uruguayo pudo apreciar una película decisiva de la estética 68, Deus e o diabo na terra do sol, de Glauber Rocha. Sentado a su lado, como guía teórico e ideológico certero en las contradicciones de la secularización latinoamericana, estaba Antonio Candido (...) Podríamos pensar que se da con Rama lo que más tarde Haroldo de Campos señalará en Antonio Candido, el secuestro del barroco en la formación de la literatura transculturadora. Por eso es bueno observar que la modernidad letrada, por ser pedagógica, trabaja con modelos y antimodelos. En ese sentido, Rama es lo suficientemente sensible como para detectar la condición alterna del artista rebelde e inconformista en otro artista anestético, Chico Buarque de Hollanda, a quien no duda en calificar de infantil, aunque, a diferencia de Glauber, vea en Chico a un auténtico transculturador. Por eso cabe pensar que, si juzgamos a Glauber como un caníbal, un radical que deglute sin piedad a Eisenstein, Welles, Visconti, Buñuel, Godard o Rosellini, es difícil justificar las restricciones de Rama ya que, en último análisis, su modelo de la transculturación narrativa latinoamericana no es otra cosa sino la actualización de la antropofagia oswaldiana de la cual, mejor que cualquier otro artista, deriva Glauber Rocha. (2008:206) 
Para Antelo, América Latina supone pensar no ya «dos Américas» — como lo hizo Ureña— sino dos grandes líneas de modernidades, una central-hegemónica y otra excéntrica-periférica. Así, el pensamiento de Rama, aunque marxiano, participa de una línea de modernidad central, caracterizada por la pedagogía, el trabajo, la racionalidad e, incluso, el disciplinamiento. Mientras que Rocha, nietzscheano al igual que el brasileño Oswald de Andrade, participa de una línea de modernidad excéntrica, caracterizada por la transgresión, el ocio, la imaginación y, por consiguiente, el barroco pero con la antropofagia. El barroco o, mejor: neobarroco, es lo que, como dice Silvana Santucci, «hace legible» la sutil latencia «del dinamismo excéntrico» de los «posicionamientos modernos de la subjetividad» (188) presentándose, por consiguiente, en una configuración de fuerzas estéticas que definen la modernidad novomundana (Link 2009:322-324, Díaz 2015a:639).

En ese marco la antropofagia se presenta como la teoría latinoamericana producto de la relación fallida o tortuosa de Brasil con América Latina. No sólo porque explica los fenómenos transculturales relevados y teorizados por Rama, sino porque como intentaré demostrar despliega un alcance mayor: a) designa un conjunto de relaciones con lo viviente que permite analizar, b) sintetiza relaciones de saber-poder constituyendo una retombée de los estudios poscoloniales, c) en tanto figura define -al igual que el homo saccer para Agamben - el campo de excepción de la modernidad colonial latinoamericana, d) introduce formas de la temporalidad que son, naturalmente, formas de la materia, de la físis. Se trata, como dice Viveiros de Castro, de una metafísica completa. Y se suma, cómo ignorarlo, de manera especial a esta lista de los secuestros.

El primero sería el que acusa el propio Antelo. Si una teoría es una generalización que a su vez se basa en un fenómeno que intenta comprender, es demasiado llamativa la ausencia de la antropofagia no tanto como caso crítico sin visitar por Rama sino como partícipe ausente de la formulación teórica -el manifiesto antropofágico es un documento famosísimo del vanguardismo brasileño—y, finalmente, la obturación o resistencia de leer eso mismo — la antropofagia como transculturación - frente a un caso contemporáneo: el cine de Glaubert.

En segundo lugar, el documento que sintetiza filosóficamente una teoría de la antropofagia en y más allá de Latinoamérica fue sencillamente excluido de toda inserción institucional. Me refiero a la Crisis de la filosofía mesiánica texto que escribió Oswald de Andrade (2008) en 1950 para concursar en la cátedra de Filosofía de la Universidad de San Pablo y que, a tono con los secuestros y las resistencias, fue rechazado. Por último, el mismo Fernández Retamar excluyó la reflexión antropofágica de Oswald de su ensayo de 1971 titulado Calibán. No es hasta el 2004, luego de varias reediciones, que la incorpora enmendando su «olvido» ya desde el título del ensayo, llamado ahora Todo Calibán.

A estas alturas, tenemos no pocos argumentos para hacerle frente a lo que nos han preguntado Luis Ruffato y Catia Bandera de Mello en 2016, hace apenas dos años, en la Feria del Libro de Guadalajara (El economista, 28/11/2016): «¿por qué no contamos a Brasil como América Latina?». Es evidente que la exclusión, o inclusión retarda, del Brasil al pensamiento latinoamericana supone una problemática aún sintomática en el campo de los estudios Latinoamericanos y en la literatura misma. En Argentina, por ejemplo, muchos de los programas de «Literatura Latinoamericana» no incluyen literatura brasileña en sus contenidos, algunas cátedras se continúan llamando «Literatura Hispanoamericana», y muy pocos casos hay de Cátedras enteramente dedicadas a la "Literatura Brasileña» — creo que el único caso es el de UBA, descontando la cátedras que pertenecen a las carreras de Portugués y como la propuestas de posgrados, entre las que se destaca el Programa 
de Cultura Brasileña de la Universidad de San Andrés-. En el plano de la investigación, aún se insiste en la vacancia de estudios que aborden la literatura y cultura brasileña desde una perspectiva latinoamericanista. ${ }^{6}$ Finalmente, y como acabamos de ver, se trata de una problemática denunciada por los mismos escritores.

Sin embargo, sería igualmente erróneo suponer que dicha situación no haya cambiado en nada. Con el cambio de siglo todo parece indicar que las mutaciones de la imagen de la literatura coincide (y no sólo temporalmente) con una transformación de la imaginación geopolítica de América Latina. Lo que puede advertirse, con simpleza, en la modificación por parte de la mayoría de los países latinoamericanos de la forma de nombrar aquel día de 1492 en que Rodrigo de Triana avistó el Nuevo Mundo.? O, calando más hondo, y con los términos de Josefina Ludmer, diríamos, por ejemplo, que «La crisis y reformulación de lo político (y de las políticas representativas tradicionales y hasta de los sistemas políticos y los Estados) que acompaña en América latina a los procesos económicos culturales de los últimos años, sería también una crisis y reformulación de la relación entre literatura y política, de su forma de relación» (155).

En ese sentido, para explorar estas conjeturas del presente que reorganizan la cámara de ecos latinoamericana, me gustaría detenerme en —o, mejor: detener, por la vía del ralentí y del ritornello- algunas figuras que desde 1492 al presente aparecen con insistencia en la literatura y las otras artes latinoamericanas agitando potencias imaginarias. Me refiero a las sirenas, a los caníbales, a lo primitivo, a lo térreo, a lo orgánico y a lo mágico como figuras y/o elementos paradigmáticos que ponen de relieve a Brasil en relación con la imagen de América Latina. Y, a partir de ellos, procuraré revisar la relación de tales elementos con determinadas imágenes del arte que se han compuesto en diferentes momentos históricos: en el siglo II en Grecia; en 1493, y los siglos XVI-XVIII en el Nuevo Mundo, en 1928 y en los años 40 y 50 en Brasil, para finalmente llegar al cambio de siglo latinoamericano.

\section{El canto y los sirenos}

El 9 de enero de 1493 Cristóbal Colón deja constancia en su diario del encuentro extraordinario del que había participado su Almirante que, cuando «iba al Río del Oro, dijo que vido tres sirenas que salieron bien alto de la mar, pero no eran tan hermosas como las pintas, que en alguna manera tenían forma de hombre en la cara. Dijo que otras veces vido algunas en Guinea, en la costa de la Managueta» (217).

Las sirenas son, en efecto, un caso paradigmático de las relaciones entre «figura» e «imagen». Su recorrido transfigurativo constituye una de las supervivencias claves de la cultura a lo largo de la historia y del mundo. En las vasijas griegas las sirenas eran seres mitad mujer y mitad pájaro. Pero desde la edad media hasta nuestros días (como nos muestra La sirenita de Disney) podemos ver el recorrido de canonización de una nueva figura: las plumas han sido remplazadas por escamas, la sirena ya no tiene garras sino una cola de pez.

En la literatura occidental el encuentro fundamental con las sirenas es el que tiene lugar en la Odisea. Sin embargo, con la literatura del Nuevo Mundo se abre un camino lateral. Las sirenas, ahora masculinizadas (sirenos deberíamos decir), exponen el terror a lo desconocido y la fiebre imaginaria con la que inicia la teodicea colonial: el deseo o el impulso por reconocer (y, a la vez, instaurar) órdenes mitológicos, culturales e imaginarios. Esos órdenes son parte de un mismo movimiento que, aunque complejo, es bien evidente puesto que está señalado por la supervivencia 
figural de las sirenas: se inicia con la extinción del matriarcado (el «mundo loco» de Medea) ante el surgimiento del patriarcado griego (cuando despluman las sirenas), y pasando por Tordesillas llega al Nuevo Mundo del mismo modo que aparece en «Guinea» o «en la costa de la Managueta». Lezama lo ha expresado en otros términos:

La gramática latina y la disciplina regionaria peinaban verbos y reducían naturaleza e instintos. Así, se ha podido afirmar que en la raíz de la expresión hispánica está la lucha entre la gramática latina y el celta rebelde. Y en los más grandes escritores nuestros, de Sarmiento a Martí, ese combate perdura con una eficacia que aconseja su permanencia. (1973:463)

La permanencia de la que habla Lezama no es de nada sino de una tensión, no ya entre civilización y barbarie sino entre patriarcado y matriarcado, o mejor, entre cultura e imagen. Es decir, por un lado la pasión clasificatoria de los dioses griegos; y por el otro las sirenas, monstruos ctónicos y deidades matriarcales, que se nos presentaran como la pura potencia de desclasificación: el canto.

Está en lo cierto Noé Jitrick, Cristóbal Colón no es el punto de inicio de nada, aunque sí, los elementos o nudos que en él se encuentran podrían constituir una constante que, «con toda la cautela del caso, caracterizaría la escritura latinoamericana» (36). Constante que ya se percibe en el cronista de Indias que, como dice Lezama, «lleva la novela de caballería al paisaje» (AA. VV::464). Entonces, si en el Diario de Colón los sirenos saltan junto con los delfines sobre la costa, Bernal Días del Castillo puebla al bosque de hechizos, como así también, los viejos bestiarios y fabularios son la forma de reconocer la flora y la fauna del Nuevo Mundo; la misma fiebre imaginaria hará que Gonzalo Hernández de Oviedo llame «dragones a los lagartos» y que cada animal recién descubierto lleve «a los conquistadores al recuerdo de Plinio el viejo» (464). Concluye Lezama:

América, en los primeros años de conquista, la imaginación no fue «la loca de la casa», sino un principio de agrupamiento, de reconocimiento y de legítima diferenciación (...) La imagen producida por ese espacio que conoce, que crea una gnosis, nos cubre como una placenta que conoce, que nos protege del mundo ctónico, de la mortal oscuridad que nos podía destruir antes de tiempo. (...) Así como Europa (...) ha marchado desde las fábulas a los mitos, en América hemos tenido que ir de los mitos a la imagen. En qué forma la imagen ha creado cultura, en qué espacios esa imagen resultó más suscitante, cuándo la imagen ya no puede ser fabulación ni mito, son preguntas que sólo la poesía y la novela pueden ir contestando. Y sobre todo en qué forma la imagen actuará en la historia, tendrá virtud operante, fuerza traslaticia para que las piedras vuelvan a ser imágenes. (465)

La pregunta de Lezama es crucial: ¿qué forma de imaginación se necesita para que las ruinas de la cultura (las piedras) puedan supervivir (vuelvan a ser imagen)? Por un lado la imaginación hispánica ha presentado la imagen de Hispanoamérica como una placenta originaria que como un huevo nos aísla de la mortal oscuridad del mundo ctónico, es decir, del mundo de las sirenas que, como escribió Kafka en El silencio de las sirenas, «abrían sus garras acariciando la roca». Pero como la placenta y el huevo no están para proteger sino para abrirse sin oponer resistencia, la cualidad de la imaginación novomundana es bien diferente.

Recordémoslo una vez más: si redimere significa originalmente comprar de nuevo, en esa readquisición de lo viviente, la cultura (como placenta engañosa, dispositivo clasificatorio y máquina 
dilemática) queda del lado de la muerte y la imagen (como canto y potencia de desclasificación) del lado de la vida. En ese sentido, la readquisición de lo ctónico (lo térreo) sería la posibilidad de vida (de sobrevida) en la cual las piedras volverían a ser imagen. ¿Esa fuerza translaticia podríamos encontrarla, entonces, en las sirenas?

Aunque «sólo la poesía y la novela pueden ir contestando" la pregunta de Lezama, es sin embargo Hegel — siempre polémico con el Nuevo Mundo [Neue Welt] — ${ }^{8}$ el primero en afiebrarse por la imago. En una de sus reflexiones sobre la naturaleza, Hegel sostuvo que aunque el colorido del plumaje de los pájaros del sur tropical sea superior al de los pájaros del norte frío, estos últimos "cantan mejor, como por ejemplo el ruiseñor y la alondra, que no existen en los trópicos». Ese déficit musical tan específicamente americano quizás no se deba — reflexiona Hegel— tanto al calor tropical como al hecho de que los habitantes de la selva tengan voces chillonas, de modo que «el día en que dejen de oírse en las selvas del Brasil los sonidos casi inarticulados de hombres degenerados, ese día muchos de los plumíferos cantores producirán también melodías más refinadas». ${ }^{9}$

Tal vez Hegel esté en lo cierto. Sin embargo: ¿quién dijo que esos chillidos provienen del canto? Como Kafka precisó, las sirenas poseían un arma «mucho más terrible que el canto: su silencio». En ese sentido, la política del silencio no tiene por correlato simplemente escuchar la nada, sino también, la exposición de un cuerpo en relación con la naturaleza: las "garras acariciando la roca». Ahí, en la imagen, el chillido inarticulado. Acaso sin saberlo, Hegel devuelve a la naturaleza plumífera y a los hombres degenerados del Nuevo Mundo, la figura ctónica de las sirenas (esas plumíferas cantoras). Por esa vía, el refinamiento latinoamericano no estaría propiamente en el canto sino en las plumas. De ahí que la literatura del cambio de siglo, imagine el sidario como una colonización en la cual los sirenos son nuevamente desplumados: «La plaga nos llegó como una nueva forma de colonización por el contagio. Remplazó nuestras plumas por jeringas, y el sol por la gota congelada de la luna en el sidario» (Lemebel:115). Por esa vía, el chillido in-articulado del canto «impotente de Espíritu» (Hegel:171) no se relacionaría con la articulación del lenguaje sino con el balbuceo, y por eso, con la materialidad vital de un cuerpo. Las sirenas son voz, no lenguaje.

Como vemos, la imagen de América Latina (de sus pájaros y hombres degenerados, en este caso), readquiere (redime) el Nuevo Mundo bajo estrictas cualidades ctónicas que bien nos recuerdan a las primigenias sirenas: es decir, a la impotencia espiritual, a la materialidad de los cuerpos (las plumas), al sonido in-articulado (el canto y el chillido) y al llamado de la tierra (Brasil, las rocas). El diagrama imaginario de ese choque de fuerzas tiene la forma del balbuceo: el encuentro entre una voz y un lenguaje, donde el lenguaje irá a decir que en esa voz no hay lenguaje sino puro canto, mientras que la voz no irá a decir nada sino a exponer.

De ese modo, lo novomundano nos conduce directamente a la imagen paradigmática de América Latina. Se trata de una figura cuyo origen es, justamente, la in-articulación de la voz, la im-potencia comunicativa y un mal-decir constitutivo: el caníbal.

\section{Abaporu: biopolíticas de la antropofagia}

Aproximadamente dos meses antes del avistamiento sirenaico, el 4 de noviembre de 1492, Colón anota en su diario: «habían hombres de un ojo y otros con hocico de perros que comían hombres» (142). Luego, el martes 11 de diciembre, Colón se informa «que caniba no es otra cosa que la gente del gran Can» (166). Es decir, los taínos (parcialidad de la etnia arawak) pronuncian ante Colón el nombre cariba, para designar a los habitantes (antropófagos) de lo que todavía no era el Caribe. 
Colón oye caniba, y entiende por eso, la gente del Can. Así, para los caribes, tal nombre significaba «osado» $\mathrm{y}$ «audaz»; para los arawak, su «enemigo»; y para los europeos, los «comedores de carne humana» recién «descubiertos». Explica Link:

Los caribes atacaban a los arawak para conseguir botines y de paso capturaban a los niños a los cuales castraban y criaban para comérselos. El canibalismo ha sido comprendido como una relación de autofagia: el caníbal se come al semejante. Se trata de un evidente error de presuposición semántica y categorial, puesto que en verdad se come al que previamente se ha declarado como no-semejante (enemigo, esclavo), y por eso el canibalismo constituye un programa biopolítico que habría que poner en consonancia con las relaciones de soberanía sobre lo viviente. (2012)

¿Cuál es entonces la soberanía sobre lo viviente que supone la biopolítica caníbal? ¿Podemos deducir de ella una estética y una ética de la existencia?

En 1611, William Shakespeare se detiene en la figura del caníbal lateralmente. ${ }^{10}$ En La tempestad, Próspero (Duque de Milán) roba la isla de Caliban, para luego esclavizarlo y enseñarle su lenguaje. A esa política colonial, el «deforme» y «grotesco» Caliban, envía su maldición: «Me enseñaron su lengua, y de ello obtuve/ El saber maldecir. iLa roja plaga/ Caiga en ustedes, por esa enseñanza!» (acto I, escena 2)." Por otro lado, La tempestad también permite visualizar un programa biopolítico. En un momento dado, Próspero le advierte a Miranda: «De él [Caliban] no podemos prescindir. Nos hace el fuego/ Sale a buscarnos leña, y nos sirve/ A nuestro beneficio» (Acto 1, Escena 2). ${ }^{2}$ Es decir, Caliban es la sinécdoque (la metonimia) de todo aquél que previamente declarado como no-semejante puede - posteriormente - ser utilizado según la voluntad y el beneficio de los que lo han designado como tal, es decir, de los que se reconocen como semejantes. En ese sentido, el Caliban es reducido al estatuto de un recurso disponible que operativamente es susceptible de ser administrado (usado, explotado, integrado y exterminado). Como ya dejó ver Shakespeare (y más recientemente la crítica poscolonial): la colonización fue un programa biopolítico en cuanto administró la vida y la muerte, de unos y de otros; produciendo, gracias a esa administración, una economía colonial que sustentó y propagó determinadas formas de vida, de saber y de poder. Explica Walter Mignolo:

Dejando de lado las connotaciones particularistas y triunfalistas que el párrafo pueda evocar, y de discutir si hubiera habido o no economía capitalista mundial sin las riquezas de las minas y de las plantaciones, el hecho es que la economía capitalista cambió de rumbo y aceleró el proceso con la emergencia del circuito comercial del Atlántico, la transformación de la concepción aristotélica de la esclavitud exigida tanto por las nuevas condiciones históricas como por el tipo humano (e.g. negro, africano) que se identificó a partir de ese momento con la esclavitud y estableció nuevas relaciones entre raza y trabajo. A partir de ese momento, del momento de emergencia y consolidación del circuito comercial del Atlántico, ya no es posible concebir la modernidad sin la colonialidad, el lado silenciado por la imagen reflexiva que la modernidad (...) construyó de sí misma. ${ }^{13}$ (Mignolo 2003b:58)

¿Cuál es entonces la diferencia entre un programa y el otro? Cuenta Michel de Montaigne que unos caníbales prisioneros observaban que en la sociedad europea había 
muchas personas llenas y ahítas de toda suerte de comodidades y riquezas; que los otros mendigaban a sus puertas, descarnados de hambre y de pobreza; y les parecía también singular que (...) los necesitados pudieran soportar tal injusticia y que no estrangularan a los otros, o no pusieran fuego a sus casas..$^{14}(112)$

Del ensayo de Montaigne nos interesa la fiebre imaginaria que lo lleva a montar (y permitirnos deducir) una serie de antítesis entre la colonización y el canibalismo.

Mientras que la colonización impulsó su programa biopolítico en un discurso que solapaba la guerra poniendo en primer plano la misión civilizatoria y cristiana; el caníbal monta su programa biopolítico en la declaración de guerra contra cualquier enemigo. Mientras que la colonización promueve a través del cautiverio y de la explotación de esclavos una utilización capitalista del no-semejante; el caníbal opta por la antropofagia ritual cuya lógica no es ni la utilidad ni la concentración material de los cuerpos, sino su más absoluto derroche. Mientras que la conquista reproduce su biopolítica en el seno de su comunidad (la no-semejanza incluso entre sus conciudadanos); el caníbal entiende que semejante gesto es lo que constituye la declaración de enemistad que instaura la no-comunidad y la desemejanza: la guerra.

Por eso durante los dos o tres meses que los caníbales de Montaigne estuvieron en tierra enemiga, se mantuvieron «alegres». Y como la prisión escapaba de su comprensión guerrera apremiaban «a sus amos para que los sacrifiquen pronto; desafiándolos, injuriándolos y reprochándoles su cobardía» (109). En síntesis: imaginariamente, la soberanía de lo viviente que supone la antropofagia se diferencia cualitativamente de la impulsada por la colonización, e incluso, son antitéticas. Sin embargo, la antropofagia — como ya señalamos— no es una praxis homogénea. E incluso, en sí misma guarda lógicas bien diferentes.

Tomemos por caso la mitología griega donde el canibalismo supone otra relación con lo viviente: el resguardo del poder. Comerse al hijo era la forma de suspender la herencia paterna. Tal dinámica puede leerse en el mito de Cronos. Recordemos, por ejemplo, la pintura Saturno devorando a su hijo de Francisco de Goya (1819-1823). Canibalismo y patronazgo aparecen íntimamente unidos: como si la forma de matar al padre o de matar a los hijos sea necesariamente vía la antropofagia. Es ejemplar al respecto la Orestiada de Esquilo — que como ya lo señaló Nietzsche pero también Oswald de Andrade (2008 [1950])— es uno de los textos que dan cuenta de la transición conflictiva del matriarcado al patriarcado. ${ }^{15} \mathrm{El}$ conflicto relacionado con la muerte de Agamenón no se explica sólo por la infidelidad de Clitemnestra luego asesinada por su propio hijo (Orestes) o el sacrificio de Agamenón a su hija (Ifigenia), sino también por un conflicto previo entre el padre (Tiestes) del amante (Egisto) de Clitemnestra y el padre de Agamenón: Atreo, que mató a los hijos de Tiestes, que era su hermano; y luego se los dio de comer en un banquete. De cualquier manera, las Erinias o Furias - esas deidades matriarcales que deberían aplicar la ley contra el matricidio - acaban convertidas por Atena —esa hija patriarcado, nacida directamente de la cabeza de Zéus-en meras sirvientas y Orestes es perdonado.

La tragedia de Tiestes, por lo tanto, constituye el punto anterior a la síntesis patriarcal que tiene lugar con Orestiada. La obra fue muy influyente tanto en el teatro griego como en la cultura grecolatina. Sin embargo, la versión más difundida no es griega sino latina, se trata de la compuesta por Séneca. Pues las obras sobre Tiestes compuestas por Eurípides, Aristófanes y Sófocles se encuentran perdidas. Ya Platón en Las leyes observaba con desdeño la tragedia antropofágica, y la ubicaba 
en el horizonte de sus prohibiciones. ${ }^{16}$ Hay otra versión de Tiestes que se encuentra perdida. Es la compuesta por Diógenes el Cínico. Cuyo teatro recuperaba «la oralidad poético-imitativa con todos sus riesgos, negando la existencia de caminos distintos que conduzcan a la poesía y a la filosofía» (López Cruces:66). Justamente Deleuze, que ha reflexionado largamente sobre los puntos de indiferencia entre literatura y filosofía, veía una nueva imagen de la filosofía, la anécdota y el teatro en la recuperación de Diógenes el Cínico por Diógenes Laercio. Ni presocrática ni platónica, incluso, ni siquiera "propiamente griega» las anécdotas de Diógenes Laercio exponían una singular glotonería apologética del incesto y la antropofagia.

Siendo común este último tema a Crisipo y a Diógenes el Cínico, Laercio no da ninguna explicación sobre Crisipo, pero propuso una sobre Diógenes particularmente convincente: «No consideraba tan odioso comer carne humana, como lo hacen los pueblos extranjeros, diciendo con recto juicio que todo está en todos lados. Hay carne en el pan y pan en las hierbas; estos cuerpos y tantos otros entran en todos los cuerpos por conductos ocultos, y se evaporan juntos, como lo muestra en su obra titulada Tiestes, si es que las tragedias que se le atribuyen son suyas...». ${ }^{17}$ Esta tesis, que también vale para el incesto, establece que en la profundidad de los cuerpos todo es mezcla; y no hay reglas que permitan decir que una mezcla es más mala que otra. Contrariamente a lo que creía Platón, no hay para las mezclas una medida en altura, combinaciones de Ideas que permitan definir las mezclas buenas y malas. Contrariamente a los presocráticos, no hay tampoco medida inmanente capaz de fijar el orden y la progresión de una mezcla en las profundidades de la Fisis; toda mezcla vale lo que valen los cuerpos que se penetran y las partes que coexisten. (...) ¿Cómo condenar el incesto y el canibalismo, en este dominio en el que las pasiones mismas son cuerpos que penetran otros cuerpos, y la voluntad particular un mal radical? Mediante una física de las mezclas en profundidad, los cínicos y los estoicos lo entregan, por una parte, a todos los desórdenes locales que tan sólo se concilian con la Gran mezcla, es decir, con la unidad de las causas entre sí. Es un mundo del terror y la crueldad, del incesto y la antropofagia. Y hay también, sin duda, otra parte: lo que, del mundo heracliteano puede subir a la superficie y va a recibir un estatuto totalmente nuevo: el acontecimiento en su diferencia de naturaleza con las causas-cuerpos, el Aión en su diferencia de naturaleza con el Cronos devorador. (Deleuze:97-98)

El Aión o acontecimiento, tal como explica Deleuze, no es el presente sino lo que está habiendo sido herido (un pasado próximo) y que está teniendo que morir (un futuro inminente). El acontecimiento es, dice Deleuze, que «nunca muere nadie, sino que siempre acaba de morir y siempre va a morir» (51). Así las cosas, la antropofagia es in-condenable, puesto que su temporalidad no es crónica sino aiónica. La lógica que supone, entonces, no es el resguardo de poder sino su más absoluto desperdicio. Sea para la tradición, para la comunidad, para la ética; es decir, para la soberanía de la vida. En la física del Aión, la materia y el tiempo no se retienen ni acumulan, sino que se gastan y se diseminan. Así recuperada la antropofagia, esta no se relaciona con los estados de cosas (la muerte, la vida) que responden a un mundo de las esencias. En la física de la superficie y los intersticios, el aión «subdivide hasta el infinito lo que le acecha sin habitarlo jamás» (52). Por consiguiente, «la unidad de los acontecimientos o de los efectos entre sí es de un tipo completamente distinto que la unidad de las causas corporales entre sí» (52). Entonces, Cronos: «la duración. El espacio de tiempo que hay entre la vida y la muerte. Aión: «el tiempo pleno de la vida sin muerte». Cronos: «el tiempo del reloj, del antes y el después. Aión: «el tiempo del deseo donde el reloj desaparece...». 
Cronos: el tiempo lineal-acumulacionista, el tiempo de la tradición y del capitalismo-imperial. Aión: el tiempo del mal, de la inutilidad, de la an-arché y del gasto. Cronos es en realidad quien devora; Aión, al contrario, es el dispensador infinito.

Recurramos a la imaginación historiográfica. ¿Podríamos concebir como azarosa la desaparición de semejante pensamiento? El emperador Juliano, impulsor de la cristiandad romana, se preguntaba en relación con las obras de Diógenes el Cínico: «Quién, tras leerlas, no las consideraría repugnantes y creería que no quedan por detrás de las otras — se refiere a las del cínico Enómaoen la exageración de lo abominable?». Mientras que los escritores alejandrinos moralizantes las atetizaron en el siglo II; el peripatético Sátiro y Sosícrates de Rodas, autor de unas Sucesiones, negaron que Diógenes el Cínico hubiera escrito jamás una línea (López Cruces:48). Si como señala Walter Mignolo, el Renacimiento fue un proceso de reinterpretación, selección e invención de una tradición grecolatina "pura», ¿la desaparición de las obras de Diógenes, como la desaparición en particular de las obras dedicadas a la tragedia antropófaga de Tiestes, no expone un rapto específico sobre la imagen cínica del canibalismo y, por consiguiente, una recuperación selectiva del canibalismo grecolatino?

Propongo la siguiente analogía: con el programa biopolítico de la colonización se recupera el canibalismo grecolatino, pero no en su carácter trágico, ni en su temporalidad aiónica, ni en su tradición cínica, ni en su realización en sí misma. El canibalismo grecolatino que la colonización recupera tiene por mito e imagen al Cronos devorador y la soberanía de lo viviente que trae emparejada: el ahorro, la concentración de poder, y la administración calculada de la vida de los semejantes y los no-semejantes.

Por otro lado, ¿no resulta llamativo que la interpretación deleuzeana del canibalismo cínico sea tan similar a la imagen canibalezca de América Latina? Establezcamos el juego comparativo. Dice Deleuze «Todos los desórdenes locales» tan sólo «se concilian con la Gran mezcla» (98). Dice Martí «Nuestra América mestiza» porque antes Simón Bolívar ha concluido que en el mundo colonial, en el planeta, solo hay una vasta zona para la cual el mestizaje no es el accidente sino lo que constituye el pueblo. ${ }^{18}$ Recientemente, dijo Fernández Retamar:

Nuestro símbolo no es pues Ariel, como pensó Rodó, sino Caliban. Esto es algo que vemos con particular nitidez los mestizos que habitamos estas mismas islas donde viviő Caliban: Próspero invadió las islas, mató a nuestros ancestros, esclavizó a Caliban y le enseñó su idioma para entenderse con él: ¿Qué otra cosa puede hacer Caliban sino utilizar ese mismo idioma para maldecir, para desear que caiga sobre él la «roja plaga»? (25-26)

No resulta azaroso, entonces, que la literatura latinoamericana readquiera la antropofagia por la vía regia de la mixtura y de la mal-di[c]ción: tupí or not tupí, that is the question. La afirmación de Oswald de Andrade no es meramente negativa y dilemática sino que esa es la estructura y el dictum del saber/poder que parodia: el «to be or not to be» shakespeareano. Y con la parodia, la constatación de que «sólo la antropofagia nos une. Socialmente. Económicamente. Filosóficamente» (2008:39). Dice Oswald: «única ley del mundo». Contra «todas las catequesis» y contra «la madre de los Gracos». Y sentencia: solo «me interesa lo que no es mío». Del Manifiesto antropofágico de 1928 surge en Sao Paulo el homónimo movimiento. ¿Su objetivo? La «revolución de los indios Caribes», mucho más importante que la francesa, ya que «sin nosotros, Europa ni siquiera tendría su pobre 
declaración de los derechos del hombre» (40). Antropofagia, entonces, la conversión del «Tabú en Tótem» y la búsqueda de la realidad «sin penitenciarías, del matriarcado de Pindorama» (49). Ese, el nombre que designaba, en tupí-guaraní, la tierra que hoy conocemos por Brasil.

La antropofagia imprime en el vanguardismo paulistano la recuperación (readquisición) no sólo de una poética — que incluso, comparte Borges por ejemplo en su Pierre Menard - sino de una teoría completa. Sin embargo, la cualidad de la antropofagia paulistana es que, al igual que los sirenos, marca la redención de las cualidades ctónicas de lo novomundano. Es decir, la readquisición —aunque imaginaria— de la Tierra (el matriarcado de Pindorama). Ahí, una bioestética caníbal de la impropiedad, de la profanación, del gasto, de la inutilidad, de la mutación y de la mezcla. El origen del cuadro Abaporu de Tarsila do Amaral expone ejemplarmente esa transformación de lo sensible:

Eu quis fazer um quadro que assustasse o Oswald, sabe? que fosse uma coisa mesmo fora do comum (...) O Aba-Poru era aquela figura monstruosa (...) a cabecinha, o bracinho fino apoiado no cotovelo, aquelas pernas compridas, enormes, e junto tinha um cacto que dava a impressão de um sol como se fosse também uma flor e ao mesmo tempo um sol e então quando viu o quadro o Oswald ficou assustadíssimo e perguntou: Mas o que é isso? Que coisa extraordinária! Aí imediatamente telefonou para o Raul Bopp (...) Aí o Bopp foi lá ao meu atelier (...) assustou-se também e o Oswald disse: Isso é como uma coisa como se fosse um selvagem, uma coisa do mato, e o Bopp foi da mesma opinião. Aí eu quis dar um nome selvagem também ao quadro, porque eu tinha um dicionário de Montoia, um padre jesuíta que dava tudo. Para dizer homem, por exemplo, na língua dos índios era Abá. Eu queria dizer homem antropófago, folheei o dicionário todo e não encontrei só nas últimas páginas tinha uma porção de nomes e vi Poru e quando eu li dizia homem que come carne humana, então achei jah! como vai ficar bem, Aba-Poru. E ficou com esse nome. (Ribeiro, 23 de febrero)

Fue el cuadro de Tarsila lo que inspiró la creación del Manifiesto Antropofágico y no a la inversa, como mucho tiempo se creyó. Realicemos otro juego comparativo. Recordemos los grabados de la antropofagia tupí-guaraní de Theodoro De Bry (1528-1598), de André Thever (1502-1590) o de Hans Staden (1525-1579). Por otro lado, recordemos la representación de Calibán en el óleo La tempestad de William Hogarth (1736) o, la ya mencionada pintura de Goya, Saturno devorando a su hijo. En la pintura de Tarsila el monstruo no es terrorífico, ni escalofriante, ni realista, ni grotesco. Es un monstruo cálido y natural, enraizado fálicamente con el mundo. El cuerpo, esa superficie de los efectos y los sentimientos, se impone en tamaño con relación a una cabeza disminuida. Automáticamente, los tres amigos coinciden en que aquella figura es un salvaje, un hombre de la tierra, un antropófago. Es interesante, entonces, cómo una fiebre de la imago domina el encuentro de Abaporu con los tres artistas quienes, al mismo tiempo y sin lugar a dudas, ven exactamente lo mismo. ¿Qué es el encuentro con Abaporu sino el índice de un nuevo ordenamiento de lo sensible, la germinación de una nueva estética de la existencia?

Abaporu, no ya el cuadro sino la transformación que designa, es un punto de inflexión en el arte latinoamericano. Puesto que la readquisición (redención) de la antropofagia contemporiza con una crisis de la imagen de la literatura y de las otras artes. A partir de allí, la antropofagia en tanto índice de lo ctónico y potencia transformativa, se asociara no sólo con la imagen de América Latina, sino también con el estatuto del arte latinoamericano. Y las artes plásticas brasileñas captan esa transformación de un modo singular. Detengámonos brevemente en una serie de encuentros figurales en las artes brasileñas de mediados de siglo XX. 


\section{Urutuy Yara: imágenes mágicas y orgánicas del arte}

El mismo año que Tarsila crea Abaporu, expone en París a Urutu. Titulado finalmente $O$ ovo, la obra señala una suerte de agotamiento de la pintura como lenguaje estético. Con pocos colores y formas — al igual que Abaporu— Tarsila recrea la idea de color y de forma, componiendo una clara economía que por medio de una precariedad expresiva retorna lo natural a lo simbólico, la Madre Natura a la cuna metafórica (de la civilización), situando tales elementos como el huevo en un espacio de sobrevivencia: «O ovo, como típica manifestación paleopolítica, señala pues un origen (alterno) de la tragedia, vista no ya como el privilegio atlético de una cultura superior, sino como efecto residual de la administración de los bienes escasos» (Antelo 2003:101). O sea, el vanguardismo paulistano busca en la excentricidad de la modernidad una potencia de lo primitivo.

En 1968, entrevistada para la revista Manchete por su amiga Clarice Lispector, la escultora Maria Martins definirá a su técnica compositiva — la cera perdida — como una «una placenta primordial». Dice Martins:

a cera perdida é um processo remoto, do tempo dos egípcios antigos. É cera de abelha misturada com um pouco de gordura para ficar mais macia. Ai você vai ao infinito porque não tem limites. A cera perdida é um modo de se expressar. Porque depois se recobre essa cera com silício e gesso e põe-se ao forno para que a cera derreta e deixe o negativo. Aí você vê a coisa mais linda do mundo: o bronze líquido como uma chama e que toma a forma que a cera deixou. (cfr. Antelo 2003:101)

En efecto, la cera perdida carga con las cualidades gnoseológicas y ónticas del huevo porque, como él, no opone resistencia. Es decir, la cáscara como límite, la placenta como el adentro y afuera que refleja las materialidades de las cosas. Entonces, además de sus formas, simbología y expresiones/figuras alegóricas, los mismos materiales de la obra de Martins se han vuelto a lo pre-humano: pues en la placenta y en el útero — esos espacios ovoides — está el drama de la salida animal (de la cera de abeja, de la naturaleza, de la matriz y de la vida).

1943. En la Valentine Gallery de New York, María Martins realiza la exposición Amazônia, integrada por ocho esculturas de difuso contorno figural. La curaduría discursiva asociaba cada escultura con figuras míticas. Estas eran: Yara, Yemanjá, Apuseiro, Uirapuru, Cobra Grande, Macumba, O. Boto e Aiokâ. A la exposición asiste André Bretón y queda maravillado con la carga primitiva, mítica y onírica de las esculturas de Martins: es decir, con «la tentación y la fiebre», con el «perpetuo recurso de las fuentes vitales de la naturaleza (tanto del espíritu como del cuerpo)» y con la «constante preocupación de colocar lo psicológico sobre lo cosmológico». ${ }^{19}$ Esas son las líneas que escribirá Breton en 1947, al participar del catálogo de la exposición de la artista en la Galería Julian Lévy.

Una de esas obras primitivistas, Yara (diosa del agua, elemento folklórico-mítico brasileño) tiene por subtítulo «Não esqueça nunca que eu venho dos trópicos» (trad.: «No olvides nunca que vengo de los trópicos»), luego el nombre de la sirena amazónica será sustituido por Saudade (trad.: nostalgia). Aspecto que, otra vez, se relaciona con la vertiente antropofágica del vanguardismo brasileño. En este caso, como su manifiesto: «Filhos do sol, mãe dos viventes. Encontrados e amados ferozmente, com toda a hipocrisia da saudade, pelos imigrados, pelos traficados e pelos touristes. No pais da cobra grande» (1990[1928]:47).

Vale recordar que Cobra Grande o Boiuna es también —además del mito tupí- una obra de Martins donde el animal antropomorfo que figura se funda en la flora y en la tierra en forma y 
color: blando como el lodo, verde; vaginal, ovoide y fálico a la vez. Ese fundido con la tierra propio de las obras de Martins, nos lleva a concebir a Yara como la cifra de la nostalgia por lo ctónico. Pero esa nostalgia, ¿es afirmativa o hipócrita? Al respecto, no es menor que la geografía imaginaria en la que Martins sitúa su obra sea "Amazônia» y los «trópicos». ¿Podríamos deducir, entonces, que Brasil en el pensamiento de Martins designa al Estado que no es otra cosa que la ritualización capitalista de la conexión con lo natural, es decir, con la dimensión orgánica y mágica de las cosas? ¿Ahí reside la nostalgia?

Daniel Link precisa, en relación con el encuentro entre Odiseo y las Sirenas, que su canto no existe, puesto que las sirenas no cantan nunca, es decir, su política y poética, su canto, es el desastre. Es decir, no se trata de que no canten nada, sino que las sirenas cantan, justamente, la nada: el desastre de la civilización, el trance de negatividad pura que atrae a los marineros, aquellos que quieren volver a la civilización, y peligran de ser atraídos por el trance de la "nada» y así nunca más volver (2009:15-20, ver introducción). En Macunaíma de Mario de Andrade es justamente la sirena Yara quien tienta trágicamente al homónimo «héroe psicasténico, una vez derrotado, tras su experiencia en la ciudad moderna, acogiéndolo por fin en el lecho inoperante del fondo del río, con lo que se ha de repetir una vez más la relación entre Dionisos y Ariadna» (Antelo 2006:24). La misma Martins en Deuses malditos I: Nietzsche explica esa violencia trágica como la transmutación de todos los valores pre-existentes, lo que implica otra valoración de lo viviente y de la relación vida y arte:

Ariana é a Terra, a mãe que conhece a felicidade e o sofrimento da fecundação. É a alegoria mais profunda da aptidão panteísta de participar do júbilo e do padecimento que permite aprovar e santificar as qualidades mais perfeitas e mais equivocadas da vida, o eterno desejo de procriar e carregar o fruto ambicionado, de reafirmar o sentimento da «união necessária entre a criação e a destruição». (92)

Entonces, no se trata sólo de la bioestética de la antropofagia sintetizada en Yara, sino del estado brutal de esa transformación de lo sensible en que la naturaleza viene, mediante el canto y el encantamiento, a destruir a la civilización que no sólo se alejó de ella, sino que fue en su contra al anestesiar con medios técnicos (taponcitos de cera) la potencia mágica-vital: los sentidos del cuerpo, la materia orgánica, la conexión con Madre Tierra, el canto. $\mathrm{O}$, al revés, recuperando la epistemología de Lezama, Yara expondría cómo la cultura misma se dirige a la ruina, mientras que la imagen no vendría a destruirla sino a redimirla (readquirirla).

Según lo expuesto, es conveniente redimensionar la magnitud bioestética de esa nueva transformación de lo sensible. Las experiencias artísticas que se asocian a Martins (sea ella o no su autora) suponen una lógica de la digitalidad dactilar: del resto y del rastro. Por esa vía no sólo Pindorama supervive (aquella tierra perdida en la historia) sino que las mismas obras de arte readquieren su estatuto orgánico y mágico primitivo. Algo que tempranamente supo señalar Murilo Mendes: en una era técnica, las obras de Martins constituyen el pasaje del estado mecánico al estado mágico, lo cual configura una peculiar interpretación duchampiana de su obra. ${ }^{20}$ Detengámonos, entonces, en esa interpretación.

Por ejemplo, Oitavo véu (1948) y Anna Maria (1942) están moldeados a partir del cuerpo y el rostro de su hija. Esa simple operación de modelado se intensifica en Yara. Pero no en la obra en sí misma sino en la exposición de Le gran verre. La mariée mise a un par ses célibataires, même (1915-1923) que al 
ser instalado definitivamente en el Museo de Filadelfia recibe la sobreimpresión en transparencia filtrada por la ventana de la escultura Yara que Duchamp mandó a colocar sobre el pasto, fuera del museo (Antelo 2006:24). Esa bioestética de lo orgánico, lo ctónico, lo placentario y lo materno se radicaliza en Etant donnés: Maria, la chute d'eau et le gaz d'éclairage (1946-1966). El maniquí mise a nu de Etant donnés fue moldeado sobre el cuerpo de Maria Martins: es una prótesis del cuerpo de ella, casi como una máscara mortuoria (imago), por eso la indicación de Duchamp para la curaduría fue «no tocar». Tal dislocamiento táctil sólo puede ser realizado imaginariamente, porque ese espacio es lo que vibra entre la ausencia (lo muerto) y su cáscara (el resto viviente, «O ovo»). De ahí que ese maniquí amoroso, separado del espectador por una pared de madera, lo posicione «como un fotógrafo ante el origen del mundo». Recuerda Antelo (2006:20) que L'origine du monde (1866) es un cuadro de Gustave Courbet que expone en primer plano la vagina de una mujer recostada de la que tampoco, al igual que Etant donnés, vemos ni el rostro ni los miembros superiores. En otras palabras, Dados «es una suerte de manifiesto paleopolítico en el sentido que no presupone al hombre sino que lo crea, con toda su ambivalencia», por tanto la política que desarrolla es doble: «de ahorro, frente a lo externo; y de dispendio, en lo más recóndito de sí» (Antelo 2003:101). Y así, Urutu y Yara como la Maria (Dados) y la mariée (El gran vidrio) se convierten en la horda incubadora que funciona "como una célula productora de vida, un huevo o un cuerpo cerrado», en ese espacio primordial «la relación con la materia es decisiva, la peleopolítica sostiene un matriarcado psíquico» (102). Y allí, el arte funciona como una máquina partera.

Por otro lado, en un texto titulado «Nuestra truculencia», Clarice Lispector concluye: «Nós somos Canibais, é precizo não esquecer. E respetar a violência que temos. E, quem sabe, não comêssemos a galinha ao molho pardo, comeríamos gente com seu sangue». ${ }^{21}$ En ese mismo año (1969), la autora escribe en Uma Aparendizagem ou o Livro dos Prazeres:

As pequeñas violências nos salvam das grandes. Quem sabe, se não comêssemos os bichos, comeríamos gente com o seu sangue. Nossa vida é truculenta, Loreley: nasce-se com sangue e com de sangue corta-se para sempre a possibilidade de união perfeita: o cordão umbilical. E muitos são os que morrem com sangue derramado por dentro ou por fora. É preciso acreditar no sangue como parte importante da vida. A truculência é amor também. (107)

Recordemos que la gallina es para Lispector, como Ariadna y Yara son para Martins, índice de la pura potencia ctónica (térrea) de creación y de destrucción: la creación ovípara y la destrucción gastronómica. En otro texto, dice Lispector: «Uma pessoa leu meus contos e disse que aquilo não era literatura, era lixo. Concordo. Mas há hora para tudo. Há também a hora do lixo. Este livro é um pouco triste porque eu descobri, como criança boba, que este é um mundo cão» (1998:12).

De modo que la descoberta do mundo que es correlativa de la descoberta de nossa truculência exige, más que literatura, lixo. «A hora do lixo» abarca un período relativamente corto de la obra de Lispector, período que comprende los textos posteriores a Agua viva (1973) y «representa un momento de radicalización de una trayectoria» ya presente, que «había sido leída desde el comienzo por todas las vertientes de la moderna crítica literaria brasileña como radical e idiosincrática». Por tanto «a hora do lixo», según Ítalo Moriconi, puede resumirse en un gesto estético que establece una dialéctica paradojal o ambivalente entre lo sublime y la desublimación, lo literario y lo periodístico, lo erudito-vanguardista y lo kitsch, el buen y el mal gusto, lo alto y lo bajo, la poesía y 
el cliché, lo irónico y lo sentimental»: puros entre-lugares. Valiéndonos de la «ingeniosa ecuación concretista, podemos decir que "a hora do lixo" es la puesta en escena del momento de lujo (luxo) imprescindible en la configuración de la basura (lixo) como categoría estética» (Moriconi).

Ya en los ochenta, Arthuro Carrera titula un poemario Potlatch mientras que Glauco Mattoso define su poética como una coprofagia. Uno, procura la poesía en el derroche ritual de ciertos pueblos indios, y el otro, en la pura inutilidad trash de comer mierda. Posteriormente, en el 2003, de ese objeto derrochado e inutilizado que es la basura, Washington Cucurto y Fernanda Laguna vía Eloísa Cartonera harán libros de cartón: otra máquina partera. Pues, según Kamenszain:

se trata de una máquina de vida más que de un aparato de referencias literarias (...) Entonces, se podría decir que estamos ante una verdadera máquina de parir («el germen de la vida no descansa») [Que] podría definirse como un dispositivo que asegura para la literatura argentina la circulación de objetos. No se trata de ningún invento genial y cualquier repositor puede activarla: «La máquina es fundamentalmente social y anterior con relación a las estructuras que atraviesa, a los hombres que distribuye, a las herramientas que selecciona, a las técnicas que promueve». (2007:124)

El libro de cartón es una marca distintiva de las editoriales cartoneras que, luego de la creación de Eloísa, proliferaron en el mundo. Si bien esto es cierto, no podemos ignorar su relación no sólo temática y teórica con las experiencias brasileñas que venimos tratando. Pues fue en un viaje a Salvador de Bahía, donde Laguna junto a Gabriela Berjerman y Cecilia Pavón descubrieron la literatura de cordel que, como también sabemos, nos llega de la poesía marginal de San Pablo y Rio de Janeiro producida en los sesenta y, yendo un poco más hacia «atrás», la literatura de cordel fue un fenómeno "propio» de la Edad Media en España y Portugal, y fue — antes que el libro- el primer modo en que se reprodujo la poesía oral. Es decir, es la literatura antes del origen de la literatura, y expresa no su costado moderno, civilizatorio-colonial y aristocrático, sino justamente su faz barroca y contra-institucional (Chozas).

Es decir, todo este recorrido está en función de exponer un efecto dominó que ahora podemos capturar en atraso, o sea, en su retroceso: lo que hace que los objetos se renacionalicen, atraviesen un umbral de transformación y entren a circular de una manera impensada es ese contagio de lixo y luxo, presente en la poesía como en las comunidades artístico-experimentales del 2001 en Argentina; antes en la poesía marginal brasileña y en el neobarroco, antes en las artes plásticas brasileñas vanguardistas; antes en la cultura popular de la edad media; antes en la mal-dicción calibanesca y en la mala audición colombina; antes en el canibalismo cínico.

En otras palabras, el lugar del artista y de la literatura Latinoamericana - tal como sostuvo Silviano Santiago, en concordancia con la gnoseología éxtima de la placenta y del huevo-es, en realidad, un entre-lugar: «vacío», «clandestino» y «ritual» como «imagen de liberación»:

Entre o sacrifício e o jogo, entre a prisão e a transgressão, entre a submissão ao código e a agressão, entre a obediência e a rebelião, entre a assimilação e a expressão - ali, nesse lugar aparentemente vazio, seu templo e seu lugar de clandestinidade, ali, se realizam o ritual antropófago da literatura latino-americana. (26)

Y lo monstruoso, se nos dice, es lo que expone esas fuerzas que se potencian con el cambio de siglo. ¿Se trata del impulso permanente por readquirir lo ctónico? ¿Esa sería la constante que 
domina el sentido del dominó caníbal que acabamos de exponer?22 ¿No es, en este punto, la literatura latinoamericana del cambio de siglo un entramado singular en el que estos elementos ponen en un umbral de transformación tanto la imagen de América Latina como de su literatura? ¿Y Brasil — como corpus, como imagen, como escritura y, por eso mismo, como forma de vida—no se presenta, acaso, como una experiencia a la que es preciso retornar —en el centro descentrado del latinoamericanismo-y, con ella, al conjunto de potencias imaginarias que conjura?

Si como dice Lezama «el hecho americano, está más hecho de ausencias que de presencias» (1955:130) ¿La literatura brasileña, la línea de modernidad de la que participa su barroco, su teoría de la antropofagia y la galería de monstruos que hace visibles, no suponen el colmo del hecho americano: un conjunto de ausencias, secuestros y resistencias que aún siguen operando en el campo? E, incluso, si entendemos que las tradiciones son artefactos conceptuales en sí mismos dotados de agentividad teórica, ¿no podemos dejar de ver en estos casos ausente, resistidos o secuestrados una capacidad, aún hoy, de trastocar los automatismos intelectuales de nuestros textos y tradiciones, ensanchando el "mundo de los posibles»? (Viveiros de Castro). ${ }^{23}$

Con esos interrogantes queremos suspender la reflexión. Lejos está este trabajo de responder los mismos, pues entendemos que pensar de/en Latinoamérica —o pensar con Latinoaméricasupone no tanto una respuesta cabal de estos $\mathrm{u}$ otros interrogantes sino nuevas formas de retornar al planteamiento, y con él a sus problemas. Como el poeta dijo: começo, meço, recomeço, e remeço e arremesso.

\section{Notas}

$1 \mathrm{El}$ artículo fue publicado el 20 de mayo de 1898 en $\mathrm{El}$ tiempo de Buenos Aires.

2 América latina en su literatura presentó las cifras estadísticas de las distintas lenguas y la cantidad de hablantes que se podían encontrar en el territorio. Ver el capítulo «La pluralidad lingüística» de Antonio Huoaiss (AA. VV.).

3 Dice Ortiz: «Entendemos que el vocablo transculturación expresa mejor las diferentes fases del proceso transitivo de una cultura a otra, porque éste no consiste solamente en adquirir una cultura, que es lo que en rigor indica la voz anglo-americana aculturación, sino que el proceso implica también necesariamente la pérdida o desarraigo de una cultura precedente, lo que pudiera decirse una parcial desculturación, y, además, significa la consiguiente creación de nuevos fenómenos culturales que pudieran denominarse neoculturación» (86).

4 Dice Lezama Lima en Analecta del reloj (1953): «Una realidad étnica mestiza no tiene nada que ver con una expresión mestiza. Entre nosotros han existido mestizos que han intentado expresarse dentro de los cánones del parnasianismo, y gran parte de la poesía afrocubana, en cambio, es de poetas de raza blanca...
Una expresión mestiza es un eclecticismo artístico que no podrá existir jamás» (1977:57). Así, años después en La expresión americana recurrirá a la imagen (como potencia gnósica) para entender «el hecho americano, cuyo destino está más hecho de ausencias posibles que de presencias imposibles. La tradición de las ausencias posibles ha sido la gran tradición americana y donde se sitúa el hecho histórico que se ha logrado» (130). En ese sentido, la imago es la posibilidad misma de toda historia y constituye la base de una historiografía anti-historicista e, incluso, an-arcaica pues sobrevive a sus propios archivos, a cualquier arché. Es lo que años después Lezama Lima definirá como era imaginaria (1971) pero que ya aparecía en 1957 como un programa futuro: «establecer las diversas eras donde la imago se impuso como historia» o del "cuadro de una humanidad dividida por eras correspondientes a su potencialidad para crear imágenes», pues de la imagen «depende la verdadera realidad de un hecho o su indiferencia e inexistencia» (58-59). Para un recorrido crítico más amplio ver Castro Ramírez.

5 La metodología por la cual proponemos abordar nuestras hipótesis recién planteadas recuperan la interpretación fi- 
gural que propone Eric Auerbach, según la cual, figura es una «imagen plástica». Esa postulación es lo que permite articular la analítica figural con diferentes teorías de la imagen y de la imaginación. De ahí que presente una etimología de conceptos latinos como fingere (molde), figulus (alfarero), fictor (fabricante, hacedor) o effigies (retrato). En lo que respecta a su etimología griega, figura no existe propiamente sino que se deriva de dis-

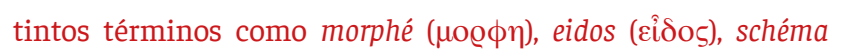

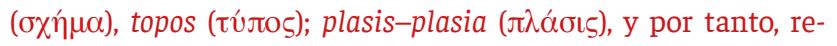
úne una constelación compleja de sentidos desarrollados por diversos autores desde Aristóteles, pasando por Varrón, hasta Lucrecio. Por otro lado, figura es una forma (morphé) como así también una idea (eidos), o sea, es una configuración sensorial (forma-idea), lo que también entendemos como imagen (Auerbach:46-47). A su vez, «configuración» debe entenderse en términos plásticos (imagen), en términos geométricos (contorno), en términos acústicos (figura verborum o imagen acústica) y en términos oníricos (sueño e imaginación). De ahí que la filología de «figura» sufra distintos pasajes: de «configuración» a «imitación» como de «prototipo original» a «copia». Esa ambivalencia conceptual es lo que sostiene la potencia conceptual del término, y lo relaciona inmediatamente con imagen (99-101)

6 Raúl Antelo, por ejemplo, hace varios años viene desarrollando un comparatismo que propone cruzar las experiencias artísticas de Argentina y Brasil como de Latinoamérica y Europa. Florencia Garramuño, Mario Cámara, Luz Horne, Gonzalo Aguilar y Álvaro Fernández Bravo se encuentran desarrollando un programa de investigación en cultura Brasileña en la Universidad de San Andrés. Cada una de sus investigaciones individuales se centra en los cruces artísticos, intelectuales o culturales entre Argentina y Brasil, o en las redes artístico-culturales del cono-sur, o los producidos en América Latina. Además, muchos de ellos han traducido literaturas brasileñas al español. Asimismo, Mario Cámara participa del proyecto argentino-brasileño Grumo (revistaeditorial) junto con Paloma Vidal (UFSP, São Paulo), Diana Klinger (UFF, Río de Janeiro) y Paula Siganevich (UBA). Todas ellas, críticas, profesoras y traductoras con intereses en los cruces literarios y culturales entre Argentina-Brasil. Por otro lado, Daniel Link siempre ha incorporado la literatura brasileña a sus clases de Literaturas del Siglo XX. Recientemente, en el 2011, Link ha organizado una maestría de Literatura Latinoamericana (UNTREF) que exige como idioma obligatorio portugués. Este panorama no es en absoluto exhaustivo, solo pretende dar cuenta del creciente y mantenido interés hacia la literatura brasileña por parte de algunos investigadores actuales.

7 El 3 de noviembre de 2010 la Presidente Cristina Fernández de Kirchner modificó por Decreto Presidencial (1584/2010) el «Día de la Raza» a «Día del Respeto a la Diversidad Cultural». En España se llamó Fiesta de la Raza (1918) y luego Día de la Hispanidad (1981); en Chile, Aniversario del Descubrimiento de América (1922) y luego Día del Encuentro entre Dos Mundos (2000); en Venezuela, primero se llamó Día de la Raza (1921) y luego, al igual que en Nicaragua, Día de la Resistencia Indígena (2002); en Costa Rica se llamó primero Día del Descubrimiento y la Raza (1968) y luego Día de las Culturas (1996); en Ecuador desde el 2011 se llama Día de la Interculturalidad; en Bolivia, pasó de llamarse «Día de la Liberación, de la Identidad y de la Interculturalidad» a «Día de la Descolonización» (2011); en Estados Unidos se celebra el Columbus Day); mientras que Cuba no celebra ni conmemora nada, en Brasil sí se celebra y conmemora pero el día de «Nossasenhora aparecida».

8 El texto original de Hegel es Vorlesungen uber die Philosophie der Geschichte. Dichas apreciaciones son realizada en su Introducción en un capítulo titulado Die NeueWelt. Realizamos estas aclaraciones puesto que las traducciones titulan el texto de diferentes maneras: como Lecciones o como Conferencias, de la filosofía de la historia (a veces adicionan universal, y otras veces no). Del mismo modo, algunas «Introducciones» no consignan el apartado Die NeueWelt. Hay muchas disquisiciones respecto de la traducción de estas citas de Hegel. Enrique Dussel ha realizado diferentes estudios filosóficos revisando estas cuestiones. Ver, por ejemplo, «De la "invención” al "descubrimiento" del nuevo mundo» en El encubrimiento del otro (1992).

9 Citado de Antonello Gerbi (1950). El capítulo «Hegel: América inmadura» del apartado «J) Los aborígenes americanos». La referencia consignada por Gerbi es Enzyklopädie, 345 Zus.; vol. VII, $1^{\mathrm{a}}$ parte, p. 489 .

10 Es decir, como anagrama de caníbal, por consiguiente, el «verdadero nombre» en español de dicho personaje — tal como descubrió Fernández Retamar- no es Cánibal ni Calibán sino Caliban. El primero acuñado por Shakespeare, con acento en la primera «a», se debió a que es anagrama del inglés cannibal. En francés, debido a «similar razón, 
de la palabra cannibale, ya presente en Montaigne, se derivó Caliban, acentuada en la segunda "a". Y en español, por contagio francés, aceptamos y propagamos (...) Calibán. En esa forma la encontramos en autores como Martí, Darío, Groussac, Rodó, Vasconcelos, Reyes, Ponce y muchos más. Pero Pedro Henríquez Ureña escribía Cáliban, fiel al original inglés, criterio que asumieron igualmente los traductores del Instituto Shakespeare, al poner en español La tempestad (Madrid, 1994). Sin embargo, en nuestra lengua, después de todo la madre del cordero, de la palabra caribe hizo caniba, y luego caníbal, cuyo anagrama lógico es Caliban (...) Me gustaría que se aceptara esta sana rectificación, a sabiendas de lo difícil que es modificar arraigados hábitos lingüísticos mal avenidos con la lógica. Por mi parte, me parece bien paradójico que un texto que se quiere anticolonialista empiece por no serlo en el título mismo» (Fernández Retamar:176-177).

11 Prefiero la traducción de Fernández Retamar antes que, por ejemplo, la traducción de la editorial Gradifco: «Me has enseñado a hablar, y mi beneficio por ello es saber cómo maldecir. ¡Qué la roja peste caiga sobre ti, por haberme inculcado tu lenguaje!» (2005:27). El original dice: «You tought me language, and my profit on't/ Is, I know how to curse. The red plague rid you/ For learning me your language!» (2000:165).

12 También en esta cita de Shakespeare la traducción común al español tiende a estilizar más de la cuenta: «Así y todo, no podemos arreglarnos sin él. Enciende nuestro fuego, sale a buscarnos leña y nos presta servicios útiles» (2005:25). En el original leemos: «We cannot miss him: he does make our fire/ Fetch in our wood and serves in offices/ That profit us» (2000:155).

13 Más allá de la explicación de Mignolo, este punto es abierto por Bhabha (175-239, 285-306) al pensar una «contramodernidad modular» que desestabiliza la modernidad colonial, que aunque se encuentra cerrada epocalmente, sus restos continúan presentes.

14 Los caníbales a los que Montaigne se refiere, más allá de la aparente ficción con la que maneja el caso, están acompañados por las fuentes históricas: en 1557 el marino Nicolás Durand de Villegaignon partió hacia Brasil, decidido a fundar una colonia que se llamaría Francia Antártica. Es decir, ignoraba que los portugueses ya se habían asentado allí. Obligado a regresar, Villegaignon se llevó a tres indios tupinambás para exhibirlos en Francia.

15 Formulaciones que se pueden leer en «Versiones del matriarcado» $\mathrm{y}$ «La crisis de la filosofía mesiánica», ambos textos complicados en Escritos antropófagos (2008), las sintetizo rápidamente. Para Andrade «la ruptura histórica con el mundo matriarcal se produjo cuando el hombre dejó de devorar al hombre para hacerlo su esclavo (...) De hecho, de la servidumbre derivaron la división del trabajo y la organización de la sociedad en clases. Se crearon la técnica y la jerarquía social. Y la historia del hombre pasó a ser, como dijo Marx, la historia de la lucha de clases» (99). Es así como la clase sacerdotal se impuso y la esclavitud se transformó en un sacrificio necesario para alcanzar el cielo: la institucionalización laboral del hombre en tanto esclavo, gracias a ese más allá eterno, se volvió soportable. De ahí — afirma Andrade — la importancia del mesianismo para el patriarcado, y por lo tanto, debemos agregar: para el capitalismo. Leyendo El origen de la tragedia de Nietzsche, Andrade concluye que en la transición del corte matriarcal-patriarcal se produce una «moral de esclavos» a través de la cual, las nuevas leyes helenas establecen al hijo como propiedad paterna y al casamiento como seno de tal legalidad; fundando en el patronazgo, la dinámica de la herencia de tierras y bienes. Andrade es interpelado por la genealogía nietzscheana y la lleva hasta sus últimas consecuencias: «La palabra ocio en griego es sxolé, de la cual deriva escuela». Especulación y conquista del espíritu tiene por etimología tal palabra. Andrade nos hace entender: «el hombre acepta el trabajo para conquistar el ocio» y no al contrario. De modo que «hoy, cuando, por la técnica y por el progreso social y político, alcanzamos la era en que, según el decir de Aristóteles, "los husos trabajan solos", el hombre deja su condición de esclavo y penetra de nuevo en el umbral de la Edad del Ocio. Es el anuncio de otro Matriarcado» (101).

16 Ver libro octavo de Las leyes cap. VIII, donde se dialoga acerca de la administración de las fiestas y las pasiones.

17 En efecto, la cita de Deleuze proviene de Diógenes Laercio. Lo podemos encontrar en el libro que trata sobre Diógenes el Cínico que pertenece a su obra Sobre las vidas, opiniones y sentencias de los filósofos más ilustres. La traducción que consigno es la de Josef Ortiz y Sanz que, aunque antigua (1792), mantiene su vigencia: «La carne, v. gr., está en el pan, y el pan en las yerbas; y así en los demás cuerpos, en todos los cuales por cierto, ocultos poros penetran las partículas y se coevaporan y unen. Esto lo hace manifiesto en su Tiestes, si acaso son suyas las tragedias que se le atribuyen, y no de Felisco Egineta su amigo, ni de Pasifonte Lucreciano, 
de quien afirma Favorino en su Historia varia, escribió después de muerto Diógenes» (356).

18 Citemos un fragmento del discurso pronunciado por Bolívar ante el Congreso de Angostura el 15 de febrero de 1819, el día de su instalación: «Tengamos en cuenta que nuestro pueblo no es el europeo, ni el americano del norte, que más bien es un compuesto de África y de América que una emanación de Europa; pues que hasta la España misma deja de ser europea por su sangre africana, por sus instituciones y por su carácter. Es imposible asignar con propiedad a qué familia humana pertenecemos. La mayor parte del indígena se ha aniquilado; el europeo se ha mezclado con el americano y con el africano, y éste se ha mezclado con el indio y con el europeo. Nacidos todos del seno de una misma madre, nuestros padres, diferentes en origen y en sangre, son extranjeros, y todos difieren visiblemente en la epidermis; esta desemejanza, trae un reato de la mayor trascendencia». Consultado en Proyecto ensayo hispánico: ensayistas. org/antologia/XIXA/bolivar/bolivar2.htm.

19 Consigno la cita completa: «É o perpétuo recurso às fontes vitais da natureza (do espírito assim como do corpo) que ela se impunha, é a sua constante preocupação de colocar o psicológico sobre o cosmológico, opondo-se à tendência contrária geralmente predominante que leva a humanidade a uma via de sofismas cada vez mais perigosa» (Breton:13).

20 El texto aparece en el Catálogo de la exposición de Maria Martins en el Museo de Arte Moderno de Rio de Janeiro (1956). Ese mismo año es publicado, el 5 junio, en el periódico de Río de Janeiro, Correio da Manhã.

21 «Nossatruculência» aparece originalmente en el Jornal do Brasil el 13 de diciembre de 1969. Posteriormente, es incluido dentro de las 466 crónicas que componen A descoberta do mundo (269).

22 Dominó caníbal es el título de una intervención curatorial de Coauthemoc Medina. En ella se articula ejemplarmente este fenómeno que venimos reseñando. Por un lado, la magnitud de la antropofagia para el arte Latinoamericano (incluso en la actualidad); y por otro lado, la coincidencia de la imagen monstruosa tanto del estatuto del arte como de América Latina (en este caso, el mundo). Cito un fragmento del texto curatorial de la exposición: «la relación entre el dominó y el canibalismo no es tan gratuita como quizá parece. Por un lado, en el Manifiesto Antropófago de 1928, el poeta brasileño Oswald de Andrade planteó la antropofagia como metáfora de la rebelión contra los mitos de la originalidad e identidad cultural (...) El juego de dominó es en sí mismo el producto de una serie de canibalismos sucesivos: se trata de un verdadero objeto transcultural. Basado en los juegos de dados chinos; llevado, como la pasta, a Italia, donde fue nombrado a partir de su similitud con el atuendo de un personaje del carnaval veneciano, acabó por ser difundido por la colonización ibérica sobre el nuevo mundo, y volverse el juego de mesa más popular de las culturas latinoamericanas. La ruta migratoria del juego que va de Catay al Caribe, pasando por las rutas europeas del capitalismo temprano, es un mapa del proceso histórico que desató al mundo moderno y que, a pesar de la paranoia que encierra, no deja de ser consignado en concepto del "efecto dominó" que imagina el peligro de una conmoción global producida por una serie de explosiones en cadena, incontrolables y sucesivas». Por eso, Dominó Caníbal se propone «como un contramodelo de los géneros usuales de invitación artística, al plantearse como una plataforma hecha de superposiciones y discontinuidades entre varios artistas que habrán de intervenir sucesiva y escalonadamente un mismo espacio, canalizando (reinterpretando, derruyendo y apropiándose) la obra de los otros participantes». El texto puede consultarse en Medina (20/10/2010).

23 Para ver el concepto de agentividad y un análisis de la teoría literaria latinoamericana en relación con la «wolrd literature» se puede consultar Rosetti.

\section{Referencias bibliográficas}

AA. VV. (1972). América Latina en su literatura. Buenos Aires: Siglo XXI/UNESCO, 1984.

Andrade, O. de (1928). Manifiesto antropofágico. A utopia antropofágica. A antropofagia ao alcance de todos.

Vol. 6. São Paulo: Globo Livros, 1990.

(2008). Escritos antropófagos. Buenos Aires: Corregidor.

Antelo, R. (2003). María Martins: el arte como prótesis de vida. Grumo, (2), 100-109. (2006). María con Marcel. Duchamp en los trópicos. Buenos Aires: Siglo XXI. 


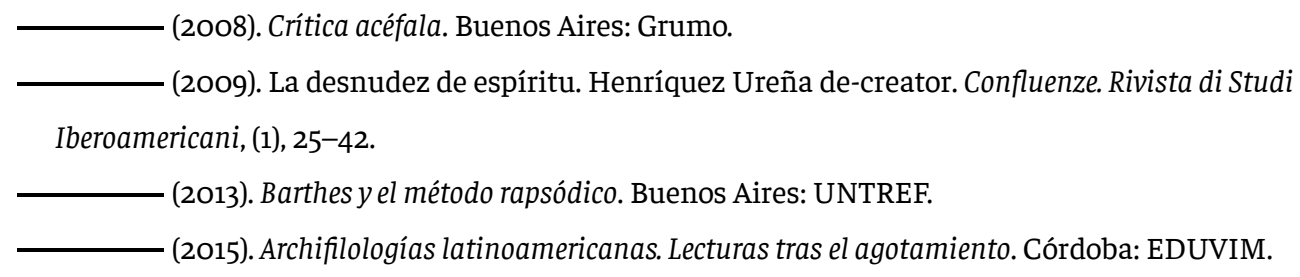

Ardao, A. (1980). Génesis de la idea y el nombre de América Latina. Caracas: Centro de Estudios Latinoamericanos.

Auerbach, E. (1998). Figura. Madrid: Trotta.

Bethell, L. (2012). Brasil y «América Latina». Prismas, Revista de historia intelectual, (16), 53-78.

Bhabha, H. (1994). El lugar de la cultura. Buenos Aires: Manantial, 2002.

Breton, A. (1947). Maria. En AA. VV. Maria Martins. [Catálogo]. São Paulo: Fundação María Luísa e Oscar Americano, 1997.

Campos, H. de (1989). O sequestro do barroco na formação da literatura brasileira: o caso Gregório de Mattos. Salvador: Fundação Casa de Jorge Amado.

Castro Ramírez, B. (2007). José Lezama Lima y su propuesta de crítica literaria para América Latina. Literatura: teoría, historia, crítica, (9), 79-122.

Chozas Ruiz-Belloso, D. (2005). La literatura de cordel brasileña y sus conexiones con la Edad Media. Especulo: Revista de Estudios Literarios, (30).

http://europa.sim.ucm.es/compludoc/AA?articuloId=424969

Colón, C. (2006). Diario de a bordo. Buenos Aires: Edaf.

Coutinho, E. (2004). La literatura comparada en América Latina: sentido y función. Voz y Escritura. Revista de estudios literarios, (14), 237-258.

Deleuze, G. (1994). Lógica del sentido. Santiago de Chile: Escuela de Filosofía de la Universidad de Arcis/Ed. Electrónica.

De Andrade, O. (1928). Manifiesto antropófago. Revista de antropofagia, (1), 3-7. (2008). Escritos antropófagos. Buenos Aires: Corregidor.

Díaz, V. (2015a). Entre España y América. Dos escenas del Barroco del siglo XX. Chuy. Revista de estudios literarios latinoamericanos, (2), 45-65. (2015b). Barroco y modernidad en la teoría estética del siglo XX. Tesis Doctoral. Buenos Aires: Facultad de Filosofía y Letras (UBA).

http://repositorio.filo.uba.ar/bitstream/handle/filodigital/4666/uba_ffyl_t_2015_69748.pdf?sequence=1

Didi-Huberman, G. (2002). Ante el tiempo. Historia del arte y anacronismo de las imágenes. Buenos Aires: Adriana Hidalgo.

Diógenes Laercio (2008). Sobre las vidas, opiniones y sentencias de los filósofos más ilustres. Madrid: Maxtor.

Fernández Bravo, Á. (2017). Comunidad y diferencia en el museo latinoamericano. El museo vacío: acumulación primitiva, patrimonio cultural e identidades colectivas Argentina y Brasil 1880-1945. Buenos Aires: EUDEBA.

Fernández Retamar, R. (2004). Todo Caliban. Buenos Aires: CLACSO.

Gerbi, A. (1950). La disputa del nuevo mundo: historia de una polémica 1750-1900. Buenos Aires: Fondo de Cultura Económica, 1960.

Hamacher, W. (2011). 95 tesis sobre filología. Buenos Aires: Miño y Dávila.

Henríquez Ureña, P. (1928). Seis ensayos en busca de nuestra expresión. Santo Domingo: Cielonaranja, 2006. (1945). Literary Currents in Hispanic America. Cambrige: Harvard University Press.

Hegel, G. W. F. (1989). Lecciones de la filosofía de la Historia. Madrid: Alianza.

Jitrik, N. (1992). Historia de una mirada: el signo de la cruz en las escrituras de Colón. México: Ediciones del Equilibrista. 
Ludmer, J. (2010). Aquí América Latina: una especulación. Buenos Aires: Eterna Cadencia.

Lemebel, P. (1996). Loco afán. Crónicas del sidario. Buenos Aires, Anagrama, 2009.

Lezama Lima, J. (1957). La expresión americana. (I. Chiampi, autor, prólogo y edición crítica). México: Fondo de Cultura Económica, 2001.

- (1977). Obras completas. T. II. México: Aguilar.

Link, D. (2009). Fantasmas. Imaginación y sociedad. Buenos Aires: Eterna Cadencia.

- (2012). Volverse caliban. Espacio Murena. www.espaciomurena.com/?p=1311

- (2015). Suturas. Imágenes, escritura, vida. Buenos Aires Eterna Cadencia.

(2016). Pedro Henríquez Ureña: filología y comparatismo. En L. Funes, coordinador.

Hispanismos del mundo: diálogos y debates en (y desde) el Sur. Buenos Aires: Miño y Dávila, 245-258.

Lispector, C. (1969). Uma Aprendizagem ou o Livro dos Prazeres. Rio de Janeiro: Nova Fronteira, 1980.

(1984). A descoberta do mundo. Rio de Janeiro: Nova Fronteira.

(1998). A via crucis do corpo. Rio de Janeiro: Rocco.

López Cruces, J. L. (2005). Diógenes y sus tragedias a la luz de la comedia. Ítaca: quaderns catalans de cultura clàssica, 47-69.

Martins, M. (1965). Deuses malditos I: Nietzsche. Rio de Janeiro: Civilização Brasileira.

Mignolo, W. (2003a). Historias locales/diseños globales: colonialidad, conocimientos subalternos y pensamiento fronterizo. Madrid: Akal.

(2003b). La colonialidad a lo largo y a lo ancho: el hemisferio occidental en el horizonte colonial de la modernidad. En E. Lander, editor. La colonialidad del saber: eurocentrismo y ciencias sociales. Una perspectiva latinoamericana., Buenos Aires: Clacso, 55-85.

Mendoza, J. J. (2012). Vanguardia, barroco, antropofagia. Revista Crítica Cultural, 7(1), 23-33.

Montaigne, M. (1999). De los caníbales. Ensayos. México: Océano, 104-110.

Moriconi, I. (2000, 12 de marzo). La hora de la basura. Página/12, Radar libros.

Ortiz, F. (1978). Contrapunteo cubano del tabaco y el azúcar. Caracas: Biblioteca Ayacucho.

Paz, O. (1950). El laberinto de la soledad. México: Fondo de Cultura Económica.

Pitol, S. (2001). Pedro Henríquez Ureña visto por sus pares. Cielo Naranja. Espacio de creación y pensamiento, dominicano y del caribe. http://www.cielonaranja.com/phu-pitol.htm

Rama, Á. (1973). Un proceso autonómico: de las literaturas nacionales a la literatura latinoamericana. Actas del VII Congrés de l'Association Internacionale de Littérature Comparée. París.

(1984). Transculturación narrativa en América Latina. Buenos Aires: El andariego, 2008.

Ribeiro, L. G. (1972, 23 de febrero). Entrevista a Tarsila do Amaral. Revista Veja. 15-17.

Rojas, R. (1924). Eurindia. Buenos Aires: Losada, 1951.

Rubén Darío (1986). Poesía completa. (Á. Rama, edición y prólogo). Buenos Aires: Biblioteca Ayacucho. (1898). El triunfo de Calibán. Revista Iberoamericana, LXIV(184/185), 451-455.

Rojas-Mix, M. (1992). América imaginaria. México: Lumen.

Rosetti, M. (2014). A contraluz: world literature y su lado salvaje. Chuy. Revista de estúdios literários latinoamericanos, (1), 60-93.

Santiago, S. (1978). Uma literatura nos trópicos: ensaios sobre dependência cultural. San Pablo: Perspectiva.

Scavino, D. (2010). Narraciones de la independencia: arqueología de un fervorcontradictorio. Buenos Aires: Eterna Cadencia.

Shakespeare, W. (1611). La tempestad. Buenos Aires: Gradifco, 2005.

(2000) The tempest. UK: Cambridge University Press.

Viveiros de Castro, E. (2010). Metafísicas caníbales. Líneas de antropología postestructural. Buenos Aires: Katz. 